\title{
炭素繊維シートと無収縮モルタルによる 道路橋標識柱基部の疲労寿命の向上
}

\author{
大倉一郎 $1 \cdot$ 橋本保則 $2 \cdot$ 酒井正和 ${ }^{3} \cdot$ 喜多伸明 $4 \cdot$ 小俣富士夫 5 \\ 1正会員 工博 大阪大学 大学院工学研究科土木工学専攻助教授 (广565-0871 大阪俯吹田市山田丘2-1) \\ ${ }^{2}$ 正会員 工修 瀧上工業株式会社 営業本部技術開発部（广454-8517 愛知県名古屋市中川区清川町2-1） \\ 3正会員 工修 三井造船株式会社 鉄構・物流事業本部技術部課長補佐 \\ （下104-8439 東京都中央区築地5-6-4）

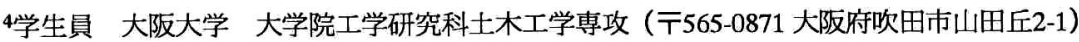 \\ 5正会員 エ博 ショーボンド建設株式会社 大阪試験室室長 \\ （干536-0022 大阪府大阪市城東区永田3-12-15）
}

\begin{abstract}
近年，高架の高速道路に設置されている門型標識柱の基部に疲労亀裂が発生していることが報告されて いる.この疲労亀裂は主に大型車の通行により生じる橋梁の振動を原因としている. 本研究では, 炭素緎 維シートと無収縮モルタルで基部を補強した場合の疲労寿命の改善効果を明らかにするために実際の基部 と同じ構造の試験体を用いて疲労試験を行なった. その結果, 炭素繊維シート補強はシートの下を疲労亀 裂が伝播する寿命を改善する効果が大きいこと，無収縮モルタル補強はリブ先端を亀裂が伝播する寿命を 改善する効果が大きいことが明らかとなった.
\end{abstract}

Key Words : carbon fiber sheet, non-shrinkable mortar, tubular signboard-column, fatigue

\section{1.はじめに}

近年，高架の高速道路に設置されている門型標識 柱の基部に，図-1 に示すような疲労亀裂が発生し ている ${ }^{1), 2)}$. 疲労亀裂は三角形リブのまわし溶接の 鋼管側の止端から発生し，鋼管の円周方向に伝播す る亀裂とリブのすみ肉溶接に沿って伝播する龟裂が 観察されている.これらの疲労亀裂は主に大型車の 通行により生じる橋梁の振動が原因であることが明 らかにされている1)-3).

このような疲労亀裂の対策として, 新設の単柱標 識柱に対してリブ形状を応力集中の小さい形状へ変 える方法4)，リブを無くした一体鍛造成型の構造") が提案されている. また，単柱の標識柱または照明 柱に作用する振動自体を低減させるために制振装置 を取り付ける方法も検討されている(-9).

既設の門型標識柱に対しては, リブの高さを高く する方法 ${ }^{2)}$ ，当て板を取り付ける方法 ${ }^{2)}$ ，リブ先端 にフランジを取り付ける方法 ${ }^{2)}$, 炭素繊維シートに より鋼管を補修する方法 ${ }^{10), 11}$ が検討されている. 配

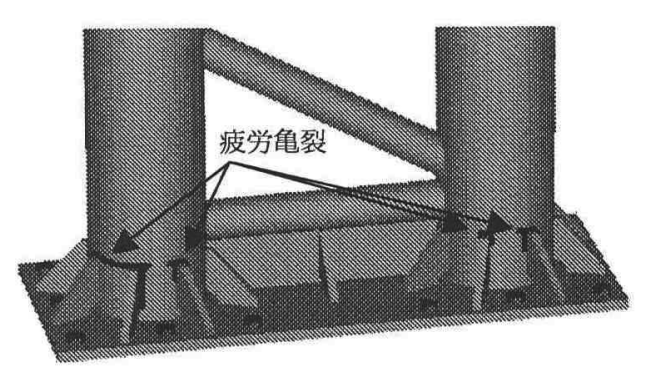

図-1 門型標識柱基部の疲労亀裂

線の点検孔から鋼管内部に無収縮モルタルを充填す ることも検討, 実施されている ${ }^{12)}$. また, 溶接止端 の形状を改良する方法もある ${ }^{13,14)}$. これらの補修・ 補強方法による門型標識柱基部の疲労寿命は2，3倍 改善されるが, 更なる疲労寿命の向上が求められて いる.

著者らは,これまで, 炭素繊維シートを貼付した 鋼板の応力低下やはく離せん断応力などの基礎的な 力学性状を明らかにしている ${ }^{15)}$.さらに実構造物へ 応用するために, ストップホールを想定した鋼板に 


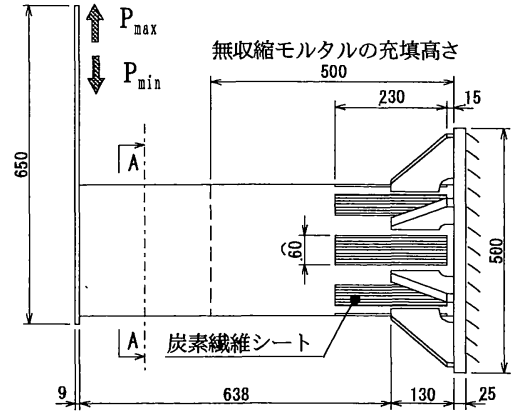

図-2 試験体

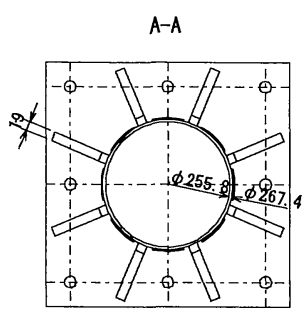

表-2 材料特性 (a) 鋼材

\begin{tabular}{|c|c|c|c|}
\hline \multirow{2}{*}{} & \multicolumn{2}{|c|}{ 鋼管 } & リブ \\
\cline { 2 - 4 } & $\mathrm{A} ・$ B シリーズ & Cシリース & \\
\hline 使用鋼材 & STK400 & STK400 & SM400A \\
\hline 実測板厚(mm) & 5.8 & 5.8 & 19.0 \\
\hline 降伏応力(MPa) & 412.0 & 411.9 & 255.3 \\
\hline 引張強度(MPa) & 458.8 & 458.5 & 426.6 \\
\hline 伸び(\%) & 37 & 39 & 31 \\
\hline ヤング率(GPa) & 208.6 & 225.7 & 196.2 \\
\hline
\end{tabular}

\begin{tabular}{|c|c|c|c|}
\hline 試験体 & $\mathrm{A} 2, \mathrm{~B} 2, \mathrm{~B} 6$ & $\mathrm{~B} 10$ & $\mathrm{C} 10$ \\
\hline 引張強度(MPa) & 53.9 & 41.0 & 44.0 \\
\hline ポアソン比 & 0.42 & 0.35 & 0.37 \\
\hline ヤング率(GPa) & 3.34 & 3.13 & 3.07 \\
\hline $\begin{array}{c}\text { 引張せん断強さ(MPa) } \\
\text { 〔JIS K 6850〕 }\end{array}$ & 16.9 & 22.7 & 23.3 \\
\hline
\end{tabular}

(c) エポキシ樹脂

表-1 試験体の一覧

\begin{tabular}{|c|c|c|c|}
\hline 試験体 & $\begin{array}{c}\text { 炭素繊維 } \\
\text { シート }\end{array}$ & $\begin{array}{c}\text { 無収縮 } \\
\text { モルタル }\end{array}$ & 載荷形式 \\
\hline $\mathrm{A} 0$ & なし & なし & 片振り \\
\hline $\mathrm{A} 2$ & 2層 & なし & 片振り \\
\hline \hline $\mathrm{B} 0$ & なし & なし & 両振り \\
\hline $\mathrm{B} 2$ & 2 層 & なし & 両振り \\
\hline $\mathrm{B} 6$ & 6層 & なし & 両振り \\
\hline $\mathrm{B} 10$ & 10 層 & なし & 両振り \\
\hline $\mathrm{C} 0$ & なし & 有り & 両振り \\
\hline $\mathrm{C} 10$ & 10 層 & 有り & 両振り \\
\hline
\end{tabular}

(b) 炭素繊維シート

\begin{tabular}{|c|c|}
\hline 炭素繊維目付け $\left(\mathrm{g} / \mathrm{m}^{2}\right)$ & 309.5 \\
\hline 密度 $\left(\mathrm{g} / \mathrm{cm}^{3}\right)$ & 1.83 \\
\hline 炭素䋐維シート 1層の換算厚さ $(\mathrm{mm}) *$ & 0.169 \\
\hline 引張強度 $(\mathrm{MPa})$ & 4020 \\
\hline ヤング率 $(\mathrm{GPa})$ & 437.3 \\
\hline
\end{tabular}

※: 炭素絨維シート 1 層の換算厚さの算出方法を 以下に示す.

1 層の換算厚さ=炭素繊維シート目付け/密度

(d) 無収縮モルタル

\begin{tabular}{|c|c|c|}
\hline 材齢 & 39 日 & 101 日 \\
\hline 圧縮強度 $(\mathrm{MPa})$ & 51.8 & 53.0 \\
\hline 引張強度 $(\mathrm{MPa})$ & 4.26 & 5.20 \\
\hline ヤング率( $(\mathrm{GPa})$ & 19.8 & 20.6 \\
\hline ポアソン比 & 0.246 & 0.229 \\
\hline
\end{tabular}

炭素繊維シートの積層数が無しと2層の2体とし, 片 振り荷重を与えた. 試験体Bシリーズは, 炭素䋐維 シートの積層数が無し，2層，6層，10層の4体とし， 両振り荷重を与えた. 試験体Cシリーズは，鋼管の 内部に無収縮モルタルを充填した。炭素繊維シート の積層数は無しと10層の2体とし, 両振り荷重を与 えた.

試験体に貼付した炭素繊維シートの大きさは長さ

\section{2. 疲労試験}

\section{(1)試験体}

炭素繊維シートと無収縮モルタルで補強した試験 体を図-2に示す. 試験体は阪神高速道路公団の付属 構造物設計図表の門型標識柱の基部にしたがい製作 した ${ }^{17)}$. 鋼管の先端には載荷のための鋼板を取り付 けている.

試験体の一覧を表-1に示す. 試験体Aシリーズは，
$230 \mathrm{~mm} \times$ 幅60mmで，繊維方向は鋼管の軸方向である. 炭素繊維シートの長さ $230 \mathrm{~mm}$ は, 炭素繊維シートと 鋼板が完全合成となるために必要な長さである ${ }^{15)}$. 炭素繊維シートの幅60mmはリブのすみ肉溶接に重な らない大きさである．炭素繊維シートの施工は，貼 付する鋼管表面を＃60の褐色アルミナ研磨材 (JIS R6111）によりブラスト処理を施した後，アイロン ローラーによってエポキシ樹脂を炭素繊維シートに 含浸させて鋼管に貼付した. 
表-3＼cjkstart無収縮モルタルの配合表

\begin{tabular}{|c|c|c|c|c|c|}
\hline \multirow{2}{*}{$\begin{array}{c}\text { J14ロート流 } \\
\text { 下值 (秒) }\end{array}$} & \multirow{2}{*}{$\begin{array}{c}\mathrm{W} /(\mathrm{C}+\mathrm{T}) \\
(\%)\end{array}$} & $\begin{array}{c}\text { カルシウムサルフォ } \\
\text { アルミネート系膨張材 } \mathrm{T}\end{array}$ & セメント $\mathrm{C}^{* 1)}$ & 細骨材 S & \multirow{2}{*|}{ 水 W } \\
\hline $8 \pm 2$ & 36.0 & \multicolumn{3}{|c|}{$1875^{* 2)}$} & 338 \\
\hline
\end{tabular}

*1 : 普通ポルトランドセメント *2: $(\mathrm{T}+\mathrm{C}): \mathrm{S}=1: 1$ で配合済み

表-4 載荷荷重

\begin{tabular}{|c|c|c|c|c|c|c|c|c|}
\hline \multirow{2}{*}{ 試験体 } & \multirow{2}{*}{$\begin{array}{c}\text { 炭素繊維 } \\
\text { シート }\end{array}$} & \multirow{2}{*}{$\begin{array}{l}\text { 無収縮 } \\
\text { モルタル }\end{array}$} & \multirow{2}{*}{ 載荷形式 } & \multicolumn{2}{|c|}{ 荷重 $P(\mathrm{kN})$} & \multirow{2}{*}{$\begin{array}{c}\text { 荷重範囲 }(\mathrm{kN}) \\
\Delta P \\
\end{array}$} & \multicolumn{2}{|c|}{ 応力範囲( $\mathrm{MPa})$} \\
\hline & & & & $P_{\max }$ & $P_{\min }$ & & $\Delta \sigma_{0 n}$ & $\Delta \sigma_{c m p}$ \\
\hline $\mathrm{A} 0$ & なし & なし & 片振り & 58.8 & 5.88 & 53.0 & 103.0 & - \\
\hline $\mathrm{A} 2$ & 2 層 & なし & 片振り & 58.8 & 5.88 & 53.0 & 103.0 & $\Delta \sigma_{c m p l}=95.8$ \\
\hline B0 & なし & なし & 両振り & 53.0 & -53.0 & 106.0 & 206.0 & - \\
\hline $\mathrm{B} 2$ & 2 層 & なし & 両振り & 53.0 & -53.0 & 106.0 & 206.0 & $\Delta \sigma_{\text {cmpl }}=191.7$ \\
\hline B6 & 6 層 & なし & 両振り & 53.0 & -53.0 & 106.0 & 206.0 & $\Delta \sigma_{\text {cmpl }}=168.0$ \\
\hline B10 & 10 層 & なし & 両振り & 53.0 & -53.0 & 106.0 & 206.0 & $\Delta \sigma_{c m p l}=149.3$ \\
\hline $\mathrm{CO}$ & なし & 有り & 両振り & 53.0 & -53.0 & 106.0 & 206.0 & $\Delta \sigma_{c m p 2}=141.9$ \\
\hline \multirow{2}{*}{$\mathrm{C} 10$} & \multirow{2}{*}{10 層 } & \multirow{2}{*}{ 有り } & \multirow{2}{*}{ 両振り } & \multirow{2}{*}{53.0} & \multirow{2}{*}{-53.0} & \multirow{2}{*}{106.0} & \multirow{2}{*}{206.0} & $\Delta \sigma_{c m p l}=152.5$ \\
\hline & & & & & & & & $\Delta \sigma_{c m p 3}=114.3$ \\
\hline
\end{tabular}

$\Delta \sigma_{c m p 1}$ : 鋼管と炭素繊維シートの完全合成断面に対する応力範囲, $\Delta \sigma_{c m p 2}$ ：鋼管とモル夕ルの完全合成断 面に対する応力範囲, $\Delta \sigma_{c m p 3}$ : 鋼管, 炭素繊維シートおよびモルタルの完全合成断面に対する応力範囲

無収縮モルタルの充填高さはベースプレート上面 から500m光とした．鋼管先端の鋼板に充填孔を設け， 試験体を直立させた状態で充填した. その後, 充填 孔にフタをして室外で1ヶ月以上養生した. なお， 試験体の鋼管内面は黒皮のままとした.

鋼材，炭素繊維シート，エポキシ樹脂，無収縮モ ルタルの材料特性を表-2に示す. 鋼材の材料特性は 3本の試験片の平均值である. 炭素繊維シートの材 料特性は検査成績書の值であり，試験に用いたすべ ての炭素繊維シートは, 同一のシートから採取した. エポキシ樹脂の引張強度, ヤング率, 引張せん断強 さは, 5本の試験片の平均值である. ポアソン比は, 引張り試験で測定された縦ひずみと横ひずみより計 算した值の平均值である.なお，エポキシ樹脂の材 料特性は室温 $20^{\circ} \mathrm{C} て ゙$ 行った結果である.

無収縮モルタルの圧縮強度, 引張強度, ヤング率 は， $\phi 5 \times 10 \mathrm{~cm}$ 供試体3体の平均值である. ポアソ ン比は, 圧縮強度試験で測定された縦ひずみと横ひ ずみより計算した值の平均值である．また，無収縮 モルタルの材料は, カルシウムサルフォアルミネー ト系膨張材を用いたプレミックスタイプを使用した. 配合表を表-3に示す.

\section{(2)載荷荷重}

図-2に示すように鋼管先端に繰返し荷重を与えた. 実際の標識柱の振動を考慮して両振り荷重を試験体 に与えた(試験体BシリーズとCシリーズ). 標識柱基 部の疲労強度に対する載荷方法の影響を調べるため に, 両振り荷重に対する比較として片振り荷重の疲

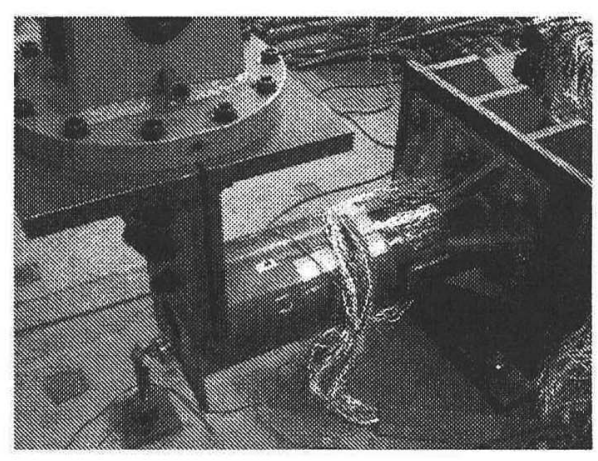

写真-1 疲労試験の様子

労試験も行なった(試験体Aシリーズ). 載荷荷重を 表-4に示す. 疲労試験の様子を写真-1に示す.

JSSC疲労設計指針 ${ }^{18)}$ によれば, リブのまわし溶 接止端の構造詳細は面外ガセットをすみ肉溶接した 継手として疲労等級 $G$ 等級に分類される. 載荷荷重 は，G等級の設計S-N曲線を用いて, 片振りの試験 体A0で24万回相当, 両振り試験体B0で3万回相当の 応力範囲となるように設定した.

また，表中の $\Delta \sigma_{0 n}$ は，鋼管の剛性のみを考慮し て構造力学によって算出されるリブ先端位置の応力 範团である. $\Delta \sigma_{c m p}$ は, 鋼管, 炭素繊維シートおよ び無収縮モルタルの完全合成断面に対して構造力学 から算出されるリブ先端の位置の応力範囲である. $\Delta \sigma_{c m p}$ はさらに3つに分類している. $\Delta \sigma_{c m p l}$ は鋼管と 炭素繊維シートの完全合成断面に対する応力範囲で ある. $\Delta \sigma_{c m p 2}$ は鋼管と無収縮モルタルの完全合成断 面に対する応力範囲である. $\Delta \sigma_{c m p 3}$ は鋼管, 炭素繊 


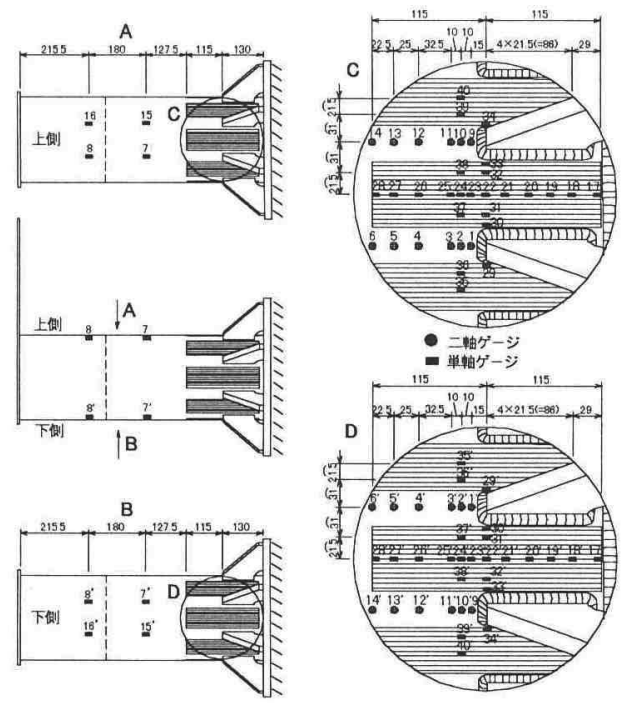

図-3 試験体 Cシリーズのひずみゲージの位置

表-5 リブのまわし溶接の脚長（単位 $\mathrm{mm}$ )

\begin{tabular}{|c|c|c|c|c|}
\hline 試験体 & リブ $\mathrm{g}$ & リブf & リブ $\mathrm{b}$ & リブ $\mathrm{c}$ \\
\hline $\mathrm{A} 0$ & 8.2 & 10.0 & 9.1 & 9.0 \\
\hline $\mathrm{A} 2$ & 6.0 & 8.9 & 10.1 & 7.5 \\
\hline $\mathrm{B} 0$ & 9.6 & 7.6 & 9.7 & 10.5 \\
\hline $\mathrm{B} 2$ & 11.0 & 12.0 & 10.5 & 9.4 \\
\hline $\mathrm{B} 6$ & 9.7 & 6.9 & 9.5 & 8.4 \\
\hline $\mathrm{B} 10$ & 7.8 & 8.0 & 8.5 & 7.2 \\
\hline \hline $\mathrm{C} 0$ & 9.2 & 10.3 & 10.1 & 9.8 \\
\hline $\mathrm{C} 10$ & 8.5 & 7.5 & 10.3 & 10.1 \\
\hline
\end{tabular}

維シートおよび無収縮モルタルの完全合成断面に対 する応力範囲である.ここで，炭素繊維シートの剛 性は表-2(b)に示す炭素纎維シート1䅉の換算厚さ， 貼付枚数およびヤング率を用いて算出した.

\section{(3)ひずみゲージの位置}

試験体に貼付したひずみゲージの位置の一例を 図-3に示す.リブと炭素繊維シートの識別記号を 図-4に示す.リブのまわし溶接の脚長は表-5に示す ようにばらつきが大きいため,ひずみゲージはリブ 先端を基準とした位置に貼付した。使用したひずみ ゲージはゲージ長 $2 m m$ の単軸ゲージと二軸ゲージで ある.ひずみゲージの貼付位置は，荷重が偏心して いないかどうかを確認するために上下・左右対称の 位置としている．ただし，試験体Aシリーズでは引 張応力が作用する鋼管の下側のみにひずみゲージを 貼付している.

炭素繊維シート上に貼付するひずみゲージは，炭 素緎維を傷つけないようにエポキシ樹脂の表面を \#1000のサンドペーパーで仕上げてから貼付した.

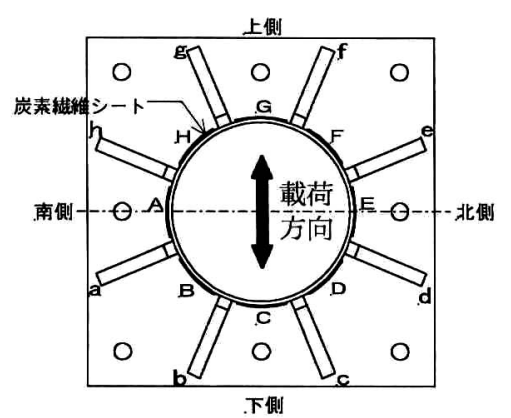

図-4 リブと炭素繊維シートの識別記号
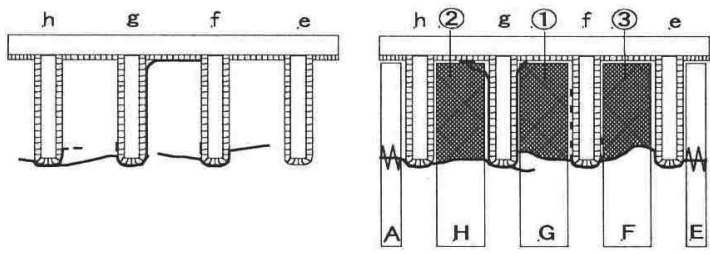

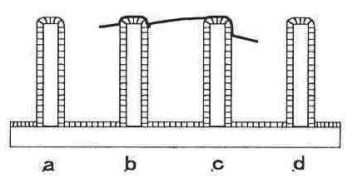

(a) 試験体 B0
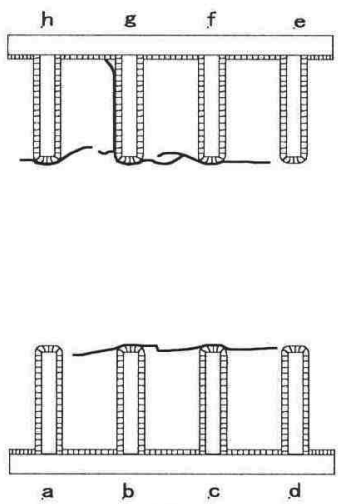

(c) 試験体 $\mathrm{CO}$

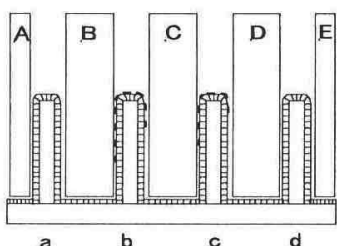

(b) 試験体 B10

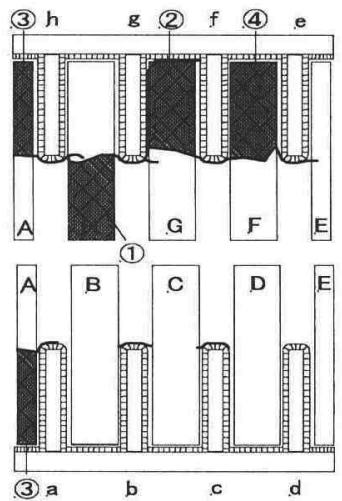

(d) 試験体 $\mathrm{C} 10$
図-5 疲労亀裂伝播状況

\section{3. 試験結果}

\section{(1)損傷状況}

破壊時における鋼管の疲労亀裂の様子の一例を 図-5に示す．本図は展開図により示している．太い 実線は鋼管の貫通亀裂を表し，太い破線は鋼管の板 厚を貫通しなかった龟裂を表している．炭素繊維シ ートがはく離した順番を(1)，(2)，(3)で示す. 炭素繊 維シートがはく離した部分を斜線で示している.

Aーは，鋼管が破壊する時に鋼管の疲労亀裂よっ て炭素繊維シートが2つに引き裂かれたことを表す。 


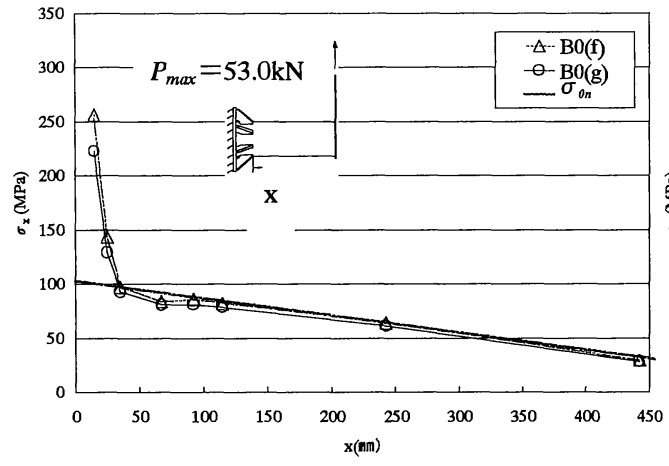

(a)試験体 B0：N=1000 回

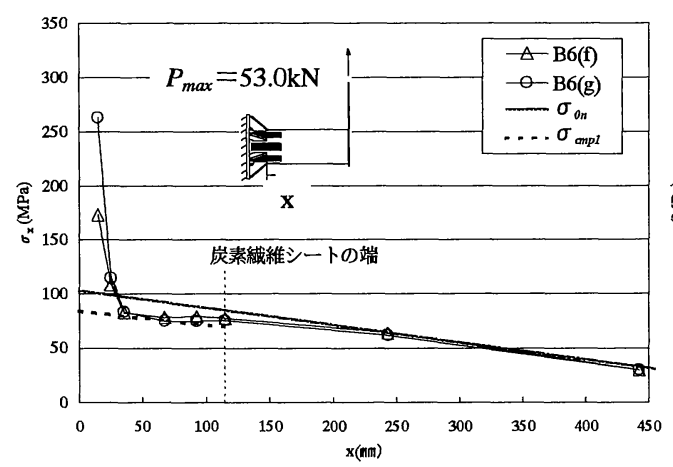

(c) 試験体 B6：N=1000 回

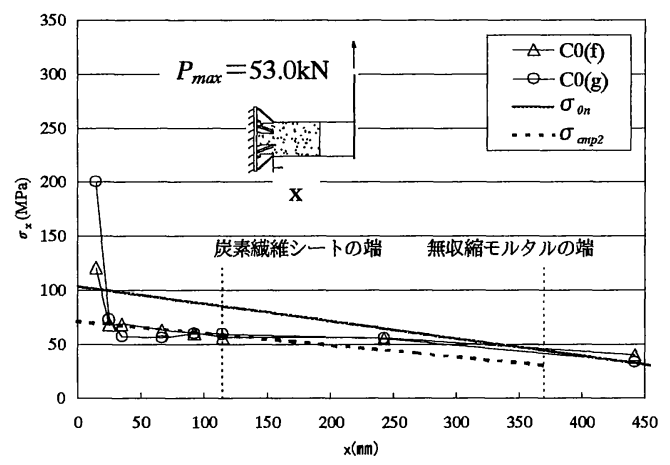

(e)試験体 C0：N=1000 回

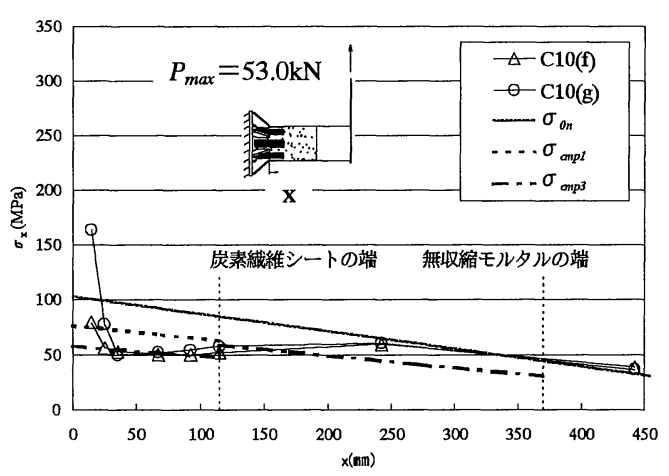

(g)試験体 C10：N=1 回

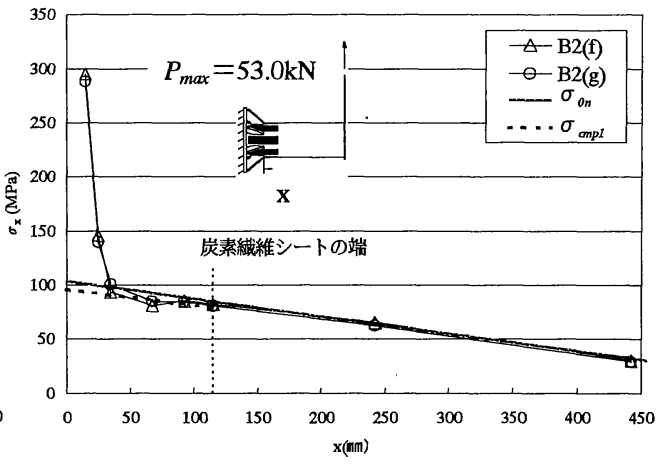

(b)試験体 B2：N=1000 回

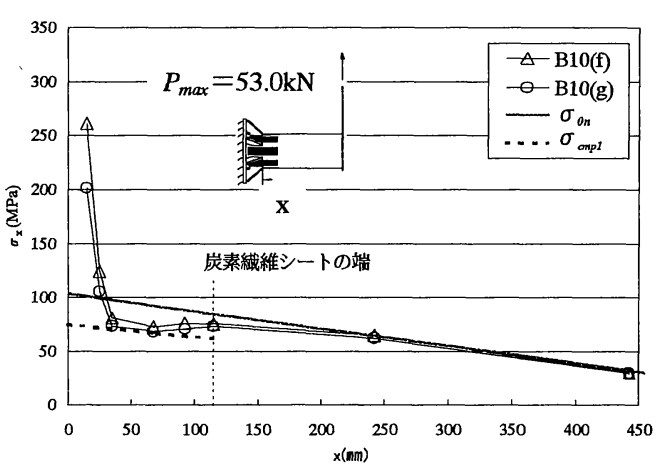

(d)試験体 B10：N=1000 回

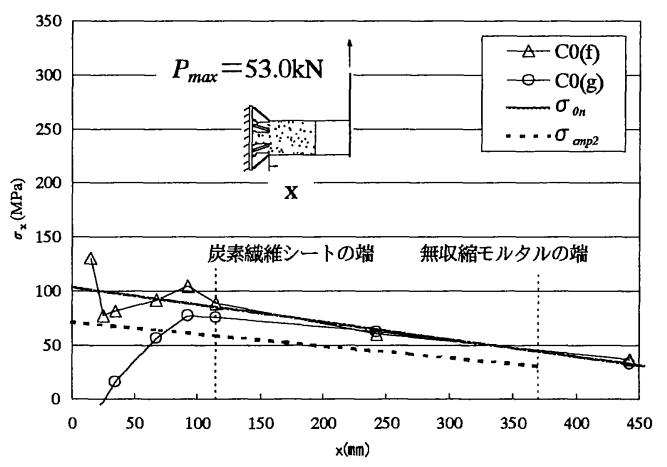

(f)試験体 C0 : N=40,000 回

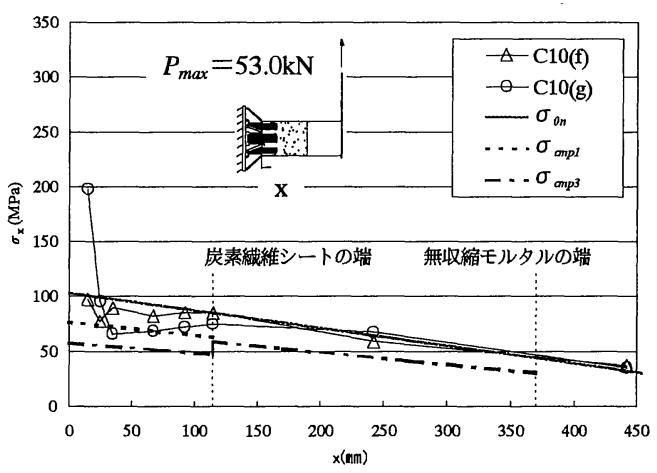

(h)試験体 C10：N=1000回

図-6 リブ前方の応力分布 
疲労亀裂は，すべての試験体において，リブのま わし溶接の鋼管側の止端から発生した.さらに，鋼 管の円周方向に伝播する疲労亀裂と，リブのすみ肉 溶接に沿って伝播する疲労亀裂が観察された. 亀裂 の進展に伴い, 亀裂周辺から徐々に炭素繊維シート が鋼管からはく離した. 最終的には円周方向の疲労 亀裂がつながり試験体が破壊した。

\section{(2)リブのまわし溶接止端の位置の応力}

炭素繊維シートおよび無収縮モルタルの補強によ るリブのまわし溶接止端の位置の応力低下を調べる. 試験体Bシリーズおよび試験体Cシリーズについて, リブ $\mathrm{f}, \mathrm{g}$ 前方の鋼管表面の応力分布を図-6に示す.

リブの識別記号は図-4に示されている.リブf，gを 選択した理由は，同部位を起点として発生した亀裂 が伝播して試験体が破壞したためである．本図は $P=53.0 \mathrm{kN}$ 時の測定ひずみから求めた応力分布であ る. また, 図中には完全合成断面の応力 $\sigma_{c m p}$ も示し ている.

a)炭素䋊維を貼付した試験体Bシリーズ

試験体Bシリーズの結果を図-6(a)〜(d)に示す.

リブ先端に近い $x=15 \mathrm{~mm}, 25 \mathrm{~mm}$ の 点の応力は, リブ先端に近づくほど計算值より大きくなる．これ は,リブがあることによる応力集中および，まわし 溶接の止端形状による応力集中の影響である. 各試 験体のこれら2点の応力は, 無補強の試験体B0の值 と比較して必ずしも小さくなっていない. したがっ て, 疲労亀裂の発生寿命に対する炭素䋐維シート補 強の効果は少ないと考えられる。

補強を施していない試験体B0のその他の応力は 計算值 $\sigma_{0 n}$ とほぼ一致する.

炭素繊維シート補強を施したBシリーズのその他 の試験体は, リブ先端からの距離 $\mathrm{x}=35 \mathrm{~mm}, 67.5 \mathrm{~mm}$, $92.5 \mathrm{~mm}$ の3点の応力が鋼管と炭素繊維シートの完全 合成断面に対する計算值 $\sigma_{c m p 1}$ とほぼ一致する。な お, 炭素繊維シートの端部の位置は $x=115 \mathrm{~mm}$ であ る.

b)無収縮モルタルを充填した試験体Cシリーズ

試験体Cシリーズに関して，リブ先端から $115 \mathrm{~mm}$ の位置に貼付したひずみゲージの值の変化を図-7に 示す.この位置のひずみゲージの值を用いた理由は, まわし溶接止端の疲労亀裂や応力集中の影響を受け ないからである. 図中の実測值は $P=53.0 \mathrm{kN}$ 時の管 軸方向のひずみである.Cシリーズでは, 無収縮モ ルタルの付着切れが原因と思われる, 繰返し回数に 伴うひずみの変化が現れた.この変化は, 試験体 $\mathrm{C} 0$ では30,000回〜 40,000回の間に現れ, 試験体 $\mathrm{C} 10$ では2回の時に現れた.したがって,ひずみの変化

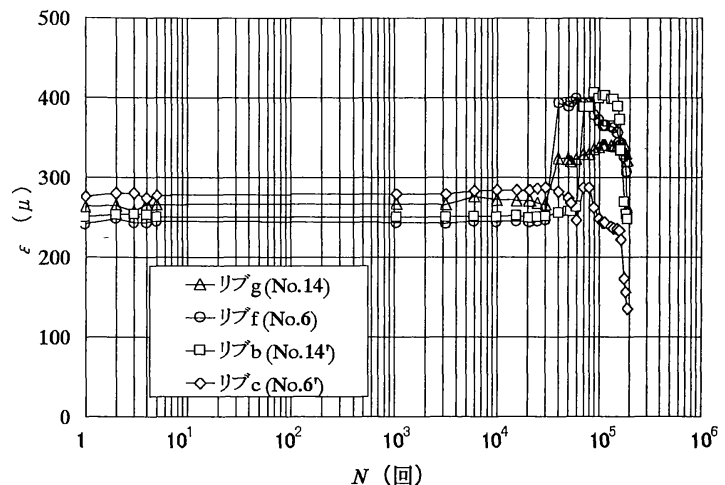

(a) 試験体 C0

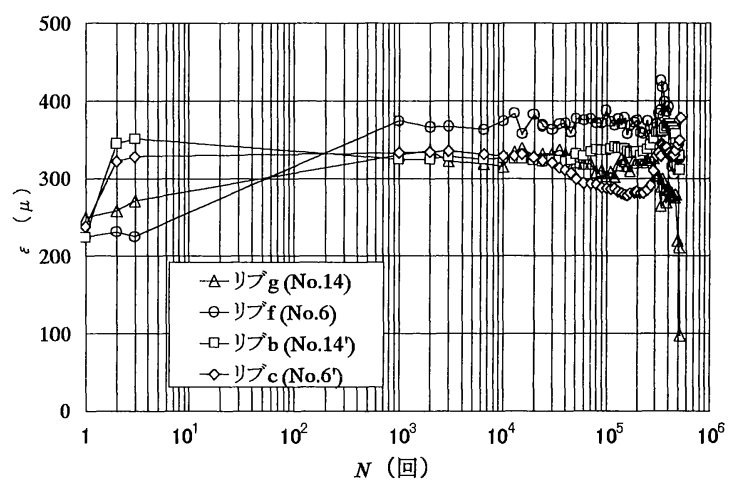

(b) 試験体 C10

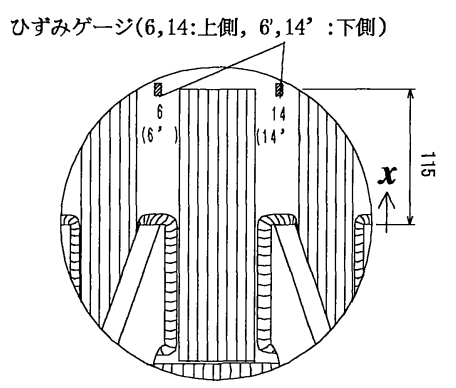

図-7 リブ先端から $115 \mathrm{~mm}$ のひずみの変化

する前後の繰り返し回数の応力分布を図-6(e)〜 (h) に示す.

試験体C0において繰返し回数 1000 回の時の応力 分布は, $\mathrm{x}=15 \mathrm{~mm}$ を除き鋼管と無収縮モルタルの完 全合成断面に対する計算值 $\sigma_{c m p 2}$ とほぼ一致する. ひずみが変化した後の繰返し回数40,000回の時の応 力分布は, リブfにおいて計算值 $\sigma_{c m p 2}$ より大きくな っている. したがって, 無収縮モルタルの付着切れ が生じたと考えられる.なお, リブgは繰返し回数 16,000回の時に亀裂が発生している。

試験体C10において繰返し回数1回の時の応力分 布は, リブ先端からの距離 $\mathrm{x}=35 \mathrm{~mm}, 67.5 \mathrm{~mm}$, 92.5mmの3点の応力が, 鋼管, 炭素繊維シートおよ 
表-6 疲労亀裂の発生寿命 $N_{\imath}$ および疲労亀裂の炭素繊維シートへの到達寿命 $N_{r}$

\begin{tabular}{|c|c|c|c|c|c|c|c|c|}
\hline \multirow{2}{*}{ 試験体 } & \multicolumn{4}{|c|}{$N_{t}\left(\times 10^{4}\right.$ 回 $)$} & \multicolumn{4}{|c|}{$N_{r}\left(\times 10^{4}\right.$ 回 $)$} \\
\hline & リブ $g$ & リブf & リブb & リブc & リブg & リブf & リブb & リブc \\
\hline $\mathrm{AO}$ & - & - & 182 & 16.0 & - & - & $190(\mathrm{C})$ & $30.0(\mathrm{C})$ \\
\hline $\mathrm{A} 2$ & - & - & 43.0 & 8.0 & 一 & - & $67.4(\mathrm{C})$ & $126(\mathrm{C})$ \\
\hline B0 & 1.2 & 3.0 & 4.8 & 2.0 & $2.0(\mathrm{G})$ & $6.1(\mathrm{G})$ & $7.0(\mathrm{C})$ & $4.8(\mathrm{C})$ \\
\hline B2 & 0.4 & 1.0 & 1.0 & 0.4 & $2.1(\mathrm{G})$ & $5.0(\mathrm{~F})$ & $6.1(\mathrm{~B})$ & $2.2(\mathrm{D})$ \\
\hline B6 & 1.5 & 5.0 & 7.8 & 5.0 & $2.5(\mathrm{G})$ & $8.0(\mathrm{G})$ & $※$ & $7.0(\mathrm{C})$ \\
\hline $\mathrm{B} 10$ & 1.8 & 4.6 & 6.1 & 6.1 & $3.4(\mathrm{G})$ & $7.9(\mathrm{G})$ & $※$ & $※$ \\
\hline $\mathrm{CO}$ & 1.6 & 13.3 & 13.3 & 3.0 & $5.0(\mathrm{H})$ & $16.0(\mathrm{~F})$ & $16.0(\mathrm{C})$ & $5.3(\mathrm{C})$ \\
\hline $\mathrm{C} 10$ & 2.0 & 16.0 & 37.0 & 1.6 & $12.0(\mathrm{H})$ & $40.1(\mathrm{G})$ & $※$ & $7.0(\mathrm{C})$ \\
\hline
\end{tabular}

$N_{r}$ に関する凡例 : ※は炭素繊維シートに到達しなかったことを示す.（）内の英字は, どの位置のシートに亀裂 が到達したかを示している. 記号の説明は図-4に示されている.

表-7 疲労寿命

\begin{tabular}{|c|c|c|c|c||c|}
\hline \multirow{2}{*}{ 試験体 } & \multirow{2}{*}{$\begin{array}{c}\Delta \sigma_{0 n} \\
(\mathrm{MPa})\end{array}$} & \multicolumn{4}{|c|}{ 繰り返し回数 $\left(\times 10^{4}\right.$ 回 $)$} \\
\cline { 3 - 6 } & $N_{\imath}$ & $N_{r}$ & $N_{f}$ & $N_{p}$ \\
\hline \hline $\mathrm{A} 0$ & 103.0 & 16.0 & 30.0 & 256.0 & 226.0 \\
\hline $\mathrm{A} 2$ & 103.0 & 8.0 & 67.4 & 474.0 & 406.6 \\
\hline \hline $\mathrm{B} 0$ & 206.0 & 1.2 & 2.0 & 10.0 & 8.0 \\
\hline $\mathrm{B} 2$ & 206.0 & 0.4 & 2.1 & 14.5 & 12.4 \\
\hline $\mathrm{B} 6$ & 206.0 & 1.5 & 2.5 & 17.9 & 15.4 \\
\hline $\mathrm{B} 10$ & 206.0 & 1.8 & 3.4 & 25.0 & 21.6 \\
\hline \hline $\mathrm{C} 0$ & 206.0 & 1.6 & 5.0 & 19.7 & 14.7 \\
\hline $\mathrm{C} 10$ & 206.0 & 1.6 & 7.0 & 52.4 & 45.4 \\
\hline
\end{tabular}

び無収縮モルタルの完全合成断面に対する計算值 $\sigma_{c m p 3}$ とほぼ一致する.ひずみが変化した後の繰返 し回数1000回の時の忘力分布は, 炭素䋐維シートの 剛性のみを考慮した $\sigma_{c m p 1}$ の近くに分布する.した がって, 繰り返し回数2回目のひずみの変化は無収 縮モルタルの付着切れと判断した.

\section{(3)疲労寿命の改善効果}

亀裂長さに応じた4種類の疲労寿命について改善 効果を述べる. 各痩労寿命の定義は以下のとおりで ある。

$N_{i}$ : 疲労亀裂の発生寿命. 図-8に示すリブ先端か ら15mmの位置のひずみゲージの值が変化した 時の繰返し回数.

$N_{r}$ : 疲労亀裂の炭素繊維シートへの到達寿命.

図-8に示す炭素繊維シート上のひずみゲージ の值が亀裂の通過により変化した時の綝返し 回数.この位置にひずみゲージが貼付されて いない試験体は, 目視観察により疲労亀裂が 炭素繊維シートへ達した時の繰り返し回数を $N_{r}$ と定義した.

$N_{f}$ : 破壊寿命. 各試験体が破断した時の繰返し回 数.

$N_{p}$ : 到達から破壊に至るまでの寿命 $\left(=N_{f}-N_{r}\right)$.

各試験体の各リブ位置における, 疲労亀裂の発生
表-8 疲労寿命の改善の度合い

\begin{tabular}{|c|c|c|c|c||c|}
\hline 試験体 & $\begin{array}{c}\Delta \sigma_{0 n} \\
(\mathrm{MPa})\end{array}$ & $N_{\imath}$ & $N_{r}$ & $N_{f}$ & $N_{p}$ \\
\hline \hline $\mathrm{A} 0$ & 103.0 & 1.00 & 1.00 & 1.00 & 1.00 \\
\hline $\mathrm{A} 2$ & 103.0 & 0.50 & 2.25 & 1.85 & 1.80 \\
\hline $\mathrm{B} 0$ & 206.0 & 1.00 & 1.00 & 1.00 & 1.00 \\
\hline $\mathrm{B} 2$ & 206.0 & 0.33 & 1.05 & 1.45 & 1.55 \\
\hline $\mathrm{B} 6$ & 206.0 & 1.25 & 1.25 & 1.79 & 1.93 \\
\hline $\mathrm{B} 10$ & 206.0 & 1.50 & 1.70 & 2.50 & 2.70 \\
\hline \hline $\mathrm{C} 0$ & 206.0 & 1.33 & 2.50 & 1.97 & 1.84 \\
\hline $\mathrm{C} 10$ & 206.0 & 1.33 & 3.50 & 5.24 & 5.68 \\
\hline
\end{tabular}

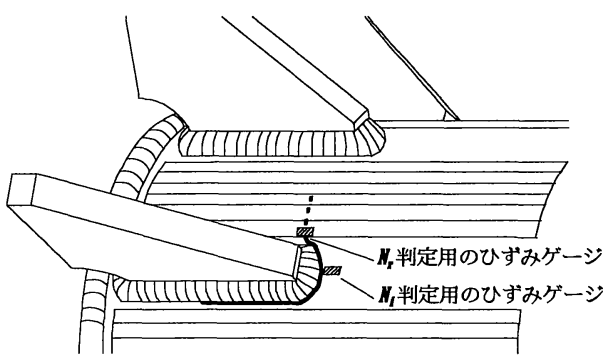

図-8 疲労寿命判定用のひずみゲージ位置

寿命 $N_{i}$ および疲労亀裂の炭素繊維シートへの到達寿 命 $N_{r}$ を表-6に示す. リブと炭素䋐維シートの識別記 号は図-4に示されている. 各試験体の疲労寿命を 表-7に示す. 疲労亀裂の発生寿命 $N_{i}$ および到達寿命 $N_{r}$ は, 各試験体の複数のリブで最も短い寿命を示し た. 表-8に疲労寿命の改善の度合いを示す. 基準と した寿命は, 試験体Aシリーズが無補強の試験体A0 とし, 試験体BシリーズとCシリーズが無補強の試 験体B0とした.

a)炭素䋊維を貼付した試験体Bシリーズ

表-6より, 試験体Bシリーズの発生寿命 $N_{i}$ および 到達寿命 $N_{r}$ はリブ位置により異なることが分かる. これは,リブのまわし溶接止端部の形状および表-5 に示す脚長の大きさが異なることによる影響である.

表-7より, 試験体Bシリーズの寿命は, 試験体B2 の発生寿命 $N_{i}$ を除いて, 炭素繊維シートの積層数を 増やすに従って改善されることが分かる . 試験体 
表-9 各補強方法による疲労寿命の改善効果

\begin{tabular}{|c|c|c|c|}
\hline $\begin{array}{c}\text { 補強方法 } \\
\text { (試験体名) }\end{array}$ & $N_{i}$ & $N_{r}$ & $N_{p}$ \\
\hline 炭素繊維シート(B10) & 小 & 中 & 大 \\
\hline 無収縮モルタル(C0) & 小 & 大 & 中 \\
\hline $\begin{array}{c}\text { 炭素繊維シート+ } \\
\text { 無収縮モルタル(C10) }\end{array}$ & 小 & 大 & 大 \\
\hline
\end{tabular}

B2の発生寿命 $N_{i}$ が改善しなかった理由は図-6(b)に 示すようにリブ先端付近の応力 $(x=15 \mathrm{~mm})$ が試験 体B0に比べて大きかったためである.

また，表-8より，試験体Bシリーズの各試験体の 疲労寿命の改善の度合いは, 発生寿命 $N_{i}$ に対する効 果が最も小さく，到達から破壊までの寿命である $N_{p}$ に対する効果が最も大きいことが分かる．したがっ て，炭素繊維シートは，炭素繊維シートの下を疲労 亀裂が伝播する寿命を改善する効果が大きい.

炭素繊維シート10層の試験体B10における改善効 果は, 無補強の試験体B0と比較して, 発生寿命 $N_{i}$ か 1.50 倍, 到達寿命 $N_{r}$ が1.70倍, 破壊寿命 $N_{f}$ が2.50倍, 到達から破壊に至るまでの寿命 $N_{p}$ が2.70倍である. b)無収縮モルタルを充填した試験体Cシリーズ

表-8より，無収縮モルタルを充填した試験体C0 は，到達寿命 $N_{r}$ に対する効果が最も大きいことから， 無収縮モルタル補強は, 疲労亀裂の初期の伝播を改 善する効果が大きいことが分かる．炭素繊維シート 10層と無収縮モルタルを併用した試験体C10は，到 達寿命 $N_{r}$ ，破壊寿命 $N_{f}$ および，到達から破壊までの 寿命である $N_{p}$ の改善効果が，全試験体の中で最も大 きいことが分かる。

無収縮モルタルを充填した試験体C0における改 善効果は, 無補強の試験体B0と比較して, 発生寿 命 $N_{i}$ が1.33倍，到達寿命 $N_{r}$ が2.50倍，破壊寿命 $N_{f}$ が 1.97倍, 到達から破壊に至るまでの寿命 $N_{p}$ が1.84倍 である．また，炭素繊維シート10層と無収縮モル夕 ルを併用した試験体C10における改善効果は，無補 強の試験体B0と比較して, 発生寿命 $N_{i}$ が1.33倍, 到 達寿命 $N_{r}$ が3.50倍，破壊寿命 $N_{f}$ が5.24倍，到達から 破壊に至るまでの寿命 $N_{p}$ が5.68倍である.

c)各補強方法の改善効果

以上より，各補強方法による改善効果の定性的な 評価を表-9にまとめる.

\section{(4)補強された標識柱基部の疲労強度}

表-7で示した各試験体の発生寿命 $N_{i}$ および到達寿 命 $N_{r}$ に関するS-N線図を図-9に示す．これは各リブ の中で最も短い寿命を用いているので安全側の評価 となる. 図中の応力範囲 $\Delta \sigma_{c m p}$ は, 鋼管と炭素繊維 シートの完全合成断面に対して構造力学から算出さ

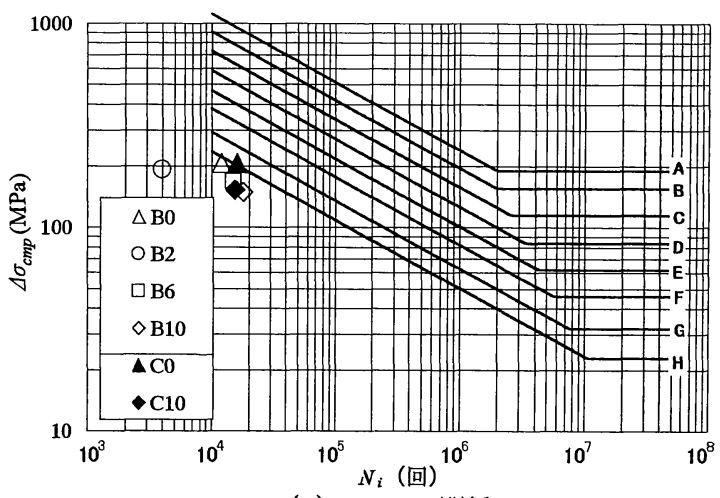

(a) $\Delta \sigma_{c m p}-N_{i}$ 関係

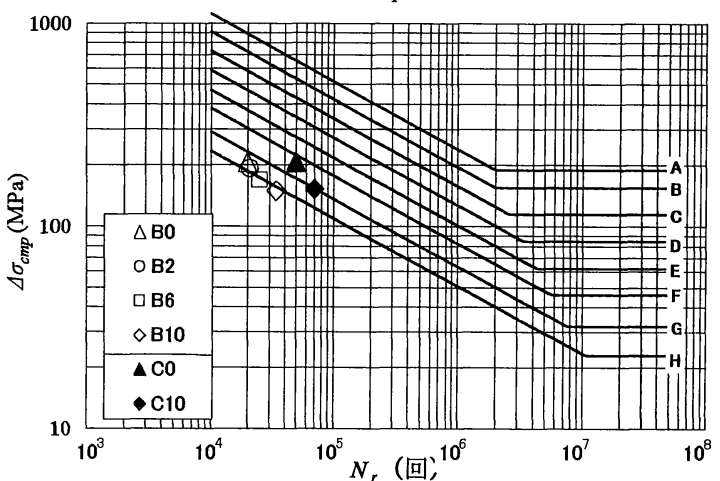

(b) $\Delta \sigma_{c m p}-N_{r}$ 関係

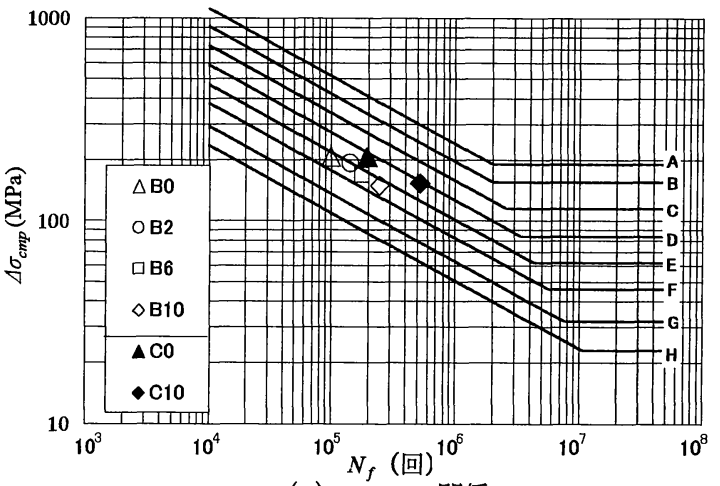

(c) $\Delta \sigma_{c m p}-N_{f}$ 関係

図-9 $\Delta \sigma_{c m p}$ で整理した S-N 線図

れるリブ先端の位置の応力範囲である，試験体Cシ リーズは無収縮モルタルが早期に付着切れしたため, その剛性を考慮しない評価としている，なお，図中 にはJSSC疲労設計指針の設計S-N線図も載せている.

図-9(a)の発生寿命 $N_{i}$ には一定の傾向がみられな いことが分かる．したがって，いずれの補強方法も 発生寿命 $N_{i}$ に対する効果は小さい。

図-9(b)の到達寿命 $N_{r}$ は，炭素繊維シートで補強 した試験体Bシリーズは疲労等級 $\mathrm{H}$ 等級線上に分布 し，無収縮モルタルで補強した試験体Cシリーズは $G$ 等級の線上に分布する. したがって, 到達寿命 $N_{r}$ は鋼管と炭素繊維シートの完全合成断面で評価する 
ことが可能である.

図-9(c)の破壊寿命 $N_{f}$ も鋼管と炭素繊維シートの 完全合成断面で評価することが可能で, 炭素繊維シ ートで補強した試験体BシリーズはF等級である. 無収縮モルタルで補強した試験体Cシリーズは同様 の評価でE等級である.これは無収縮モルタルの付 着が切れても疲労強度を1等級改善する効果がある ことを示している.

以上の結果より，炭素繊維シートにより補強され た標識柱基部の疲労設計は, 鋼管と炭素䋐維シート の完全合成断面に対して構造力学によって算出され る応力範囲 $\Delta \sigma_{c m p}$ を用い, 標識柱基部の疲労強度を 到達寿命 $N_{r}$ に対してH等級, 破壊寿命 $N_{f}$ に対してF 等級として設計すると良い. 無収縮モルタルによる 補強はその剛性を考慮せずに標識柱基部の疲労強度 を1等級上げることで設計すると良い. 到達寿命 $N_{r}$ に対してG等級，破壊寿命 $N_{f}$ に対してE等級である.

\section{(5)両振り試験と片振り試験による疲労強度の相違} 試験体Aシリーズと試験体Bシリーズの破壊寿命 $N_{f}$ に関するS-N線図を図-10に示す.Aシリーズの疲

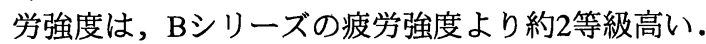
これは, 試験体 A シリーズでは, 鋼管の下側か ら亀裂が発生・伝播したのに対し, 試験体 B シリ 一ズは鋼管上下から亀裂が発生・伝播したためであ る.したがって, 片振り試験の結果で標識柱基部の 疲労強度を推定することは危険側の評価となる。

\section{4. まとめ}

炭素繊維シートおよび無収縮モルタルによる門型 標識柱の疲労寿命の向上を調べるために, 実際の基 部と同じ構造の試験体にこれらの補強を施して疲労 試験を行った．主な結論は以下のとおりである．な お, 本論文では亀裂長さに応じて 4 種類の疲労寿命 を定義した. 1 つはリブまわし溶接止端部の疲労亀 裂の発生寿命, 1 つは亀裂が伝播し炭素䋐維シート に到達するまでの寿命である到達寿命，1 つは試験 体の破壊寿命， 1 つは到達から破壊に至るまでの寿 命である。

(1) 炭素繊維シートによる補強は, 4 種類の疲労寿 命の中で到達から破壞に至るまでの寿命の改善 効果が最も大きく, 炭素繊維シートの下を疲労 亀裂が伝播する寿命を改善する効果が大きい。 また, 到達寿命と破壊寿命は, 炭素繊維シート の積層数を増やすに従って改善される. 無補強 の試験体 B0 と比較した場合, 炭素繊維シート

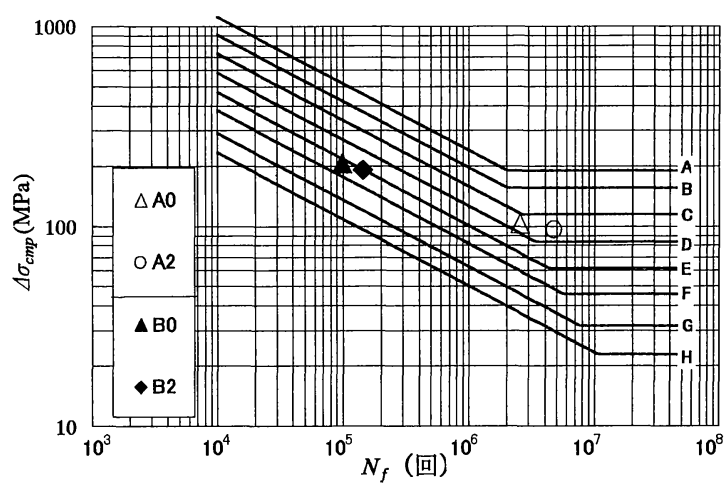

図-10 A シリーズと B シリーズの破壊寿命 $N_{f}$ の比較

10 層の試験体 $\mathrm{B} 10$ の到達寿命は 1.70 倍, 破壊 寿命は 2.50 倍であった.

（2）無収縮モルタル充填のみよる補強は，4 種類の 疲労寿命の中で到達寿命の改善効果が最も大き く, 初期亀裂が伝播する寿命を改善する効果が 大きい. 無補強の試験体 B0 と比較した場合, 無収縮モルタルを充填した試験体 C0 の到達寿 命は 2.50 倍，破壞寿命は 1.97 倍であった。

（3）炭素繊維シート 10 層と無収縮モルタルを併用 した試験体 $\mathrm{C} 10$ の破壊寿命は 5.24 倍となり， 各々の効果を掛け合わせて求まる程度に改善さ れる。

(4) 炭素繊維シート, 無収縮モルタルおよびこれら を併用して補強を行なった標識柱基部の到達寿 命は，鋼管と炭素繊維シートの完全合成断面に 対して構造力学から算出されるリブ先端の位置 の応力範囲で評価することが可能である. 炭素 繊維シートにより補強を行う場合は $\mathrm{H}$ 等級，炭 素繊維シートおよび無収縮モルタルにより補強 を行う場合は $\mathrm{G}$ 等級で設計すればよい。

(5) 炭素繊維シート, 無収縮モルタルおよびこれら を併用して補強を行なった標識柱基部の破壊寿 命も，鋼管と炭素繊維シートの完全合成断面に 対して構造力学から算出されるリブ先端の位置 の応力範囲で評価することが可能である．炭素 繊維シートにより補強を行う場合は $\mathrm{F}$ 等級, 炭 素繊維シートおよび無収縮モルタルにより補強 を行う場合は $\mathrm{E}$ 等級で設計すればよい。

(6) 両振り試験で得られる標識柱基部の疲労強度は 片振り試験のそれより低い.これは, 両振り試 験では疲労亀裂が鋼管の両側から発生・伝播す るのに対し，片振り試験では亀裂が鋼管の片側 から発生・伝播するからである.したがって， 片振り試験の結果で標識柱基部の疲労強度を推 定することは危険側の評価となる. 
本試験の応力範囲は $206 \mathrm{MPa}$ を基本とした. 応力 範囲が異なる場合は，モルタルまたは炭素繊維シー トの付着切れに関する性状も異なることが考えられ るが今後の課題である.

謝辞 : 本研究の実施に際して, 貴重な助言を賜った 三井造船株式会社の祝賢治氏とショーボンド建設株 式会社の松上泰三氏に感謝の意を表します.

\section{参考文献}

1）源野博好：門型標識柱の損傷と対策，阪神高速道路 公団技報 10 号, pp.143-150，1991。

2）吉川実，秦栄次，祝賢治，北村降理 : 門形標識柱の 柱基部に生じる亀裂の補修・補強構造とその評価, 土木学会第 49 回年次学術講演会, I-A213, pp.424425, 1994.

3）小塩達也, 李相勳, 山田健太郎, 森成顕, 森下宣 明 : 交通荷重による標識柱の振動と疲労耐久性, 構 造工学論文集, Vol.47A, pp.1009-1017, 2001.

4）本間宏二, 杉本雅一, 池田憲二, 今野久志, 三田村 浩 : 鋼管照明柱等の基部而疲労性に関する研究, 土 木学会第 56 回年次学術講演会, I-B140, pp.280-281, 2001.

5）立石一真，波多野保史，多田仁志，河崎英治，飯田 毅 : 照明柱基部の新しい接合構造の開発, 土木学会 第 57 回年次学術講演会, I-175, pp.349-350, 2002.

6) 別井仁, 飯嶋俊比古, 神山淨 : 橋梁に取り付けられ る道路照明柱の制振対策一大師橋一，橋梁と基礎， Vol.34, No.12, pp.29-34, 2000.

7）尾畑守夫, 森尻涉, 島崎洋治：照明柱に対する TRMD の制振効果, 土木学会第 57 回年次学術講演会, I-598，pp.1195-1196, 2002.

8）立石一真, 波多野保史, 多田仁志, 飯田毅, 河野健
二 : 走行荷重による高架橋上照明柱の振動計測とチ エーンダンパーの制振効果, 土木学会第 57 回年次学 術講演会, I-599, pp.1197-1198， 2002.

9）河野健二, 飯田毅, 立石一真 : チェーンダンパーに よる照明用柱振動の減衰効果に関する研究, 鋼構造 年次論文報告集，第 8 巻, pp.91-96, 2000.

10）大倉一郎，橋本保則，祝賢治，松上泰三 : 炭素䋐維 シートによる道路橋標識柱基部の疲労強度の向上, 鋼構造年次論文報告集，第 10 巻, pp.291-296, 2002.

11）山田聡, 酒井吉永, 山田健太郎 : 撤去した標識柱基 部の疲労強度とその補修方法に関する一考察, 土木 学会, 構造工学論文集, Vol.49A, pp.725-734, 2003.

12）時譲太, 宮脇潔, 奥西史伸, 石井博典 : モル夕ル充 填による既設門型標識柱の基部補強方法, 土木学会 第 56 回年次学術講演会, I-B102, pp.204-205, 2001.

13）三木干壽, 穴見健吾, 谷英樹, 杉本一朗 : 溶接止端 部改良による疲労強度向上法, 溶接学会論文集, 第 17 巻, 第 1 号, pp.111-119, 1999.

14）太田省三郎, 石村哲朗, 田村徹弥：止端部のウォー タージェット処理によるすみ肉溶接継手の疲労強度 向上, 溶接学会論文集, 第 14 巻, 第 3 号, pp.601608, 1996.

15）大倉一郎, 福井唯夫, 中村圭吾, 松上泰三 : 炭素繊 維シートによる鋼板応力の低下とはく離せん断応力, 土木学会論文集, No.689/1-57, pp.239-249, 2001.

16）大倉一郎，福井唯夫，中村圭吾，松上泰三，祝賢 治 : 炭素纎維シートの鋼板疲労亀裂補修への適用, 鋼構造年次論文報告集，第 8 巻，pp.689-696，2000.

17）阪神高速道路公団：付属構造物設計図表，1990.

18）日本鋼構造協会 : 鋼構造物の疲労設計指針・同解説, 技報堂出版，1993.

(2003.9.18 受付)

\title{
IMPROVEMENT OF FATIGUE LIFE AT BASES OF TUBULAR SIGNBOARD- COLUMNS IN HIGHWAY BRIDGES BY CARBON FIBER SHEETS AND NON- SHRINKABLE MORTAR
}

\author{
Ichiro OKURA, Yasunori HASHIMOTO, Masakazu SAKAI, Nobuaki KITA \\ and Fujio OMATA
}

Traffic vibration of highway bridges often leads to fatigue cracking at the bases of tubular columns with signboards. This paper deals with the application of carbon fiber sheets and non-shrinkable mortar to improve the fatigue life at the tubular column bases. Fatigue experiments are completed on the tubular column bases with CF sheets and/or NS mortar provided. It is shown that CF sheets improve the life when cracks propagate under CF sheets, while NS mortar increases the life until cracks reach CF sheets. 